\title{
Meta-analysis comparing incidence of grade 3-4 neutropenia with ALK inhibitors and chemotherapy in patients with non-small-cell lung cancer
}

\author{
Bernardo Rapoport ${ }^{1,2}$, Ramin B Arani ${ }^{3}$, Nicola Mathieson ${ }^{4}$ \& Andriy Krendyukov*,4 \\ ${ }^{1}$ The Medical Oncology Centre of Rosebank, Johannesburg, 2196, South Africa \\ ${ }^{2}$ Department of Immunology, Faculty of Health Sciences, University of Pretoria, Pretoria, 0084, South Africa \\ ${ }^{3}$ Biostatistics, Sandoz Inc., Princeton, NJ 08540, USA \\ ${ }^{4}$ Oncology/Hematology, Hexal AG, 83607 Holzkirchen, Germany \\ *Author for correspondence: akrendyukov@gmx.de
}

\begin{abstract}
Aim: This meta-analysis compared incidence of grade 3-4 neutropenia with ALK inhibitors versus chemotherapy in patients with non-small-cell lung cancer. Materials \& methods: PubMed/MEDLINE was searched to identify Phase II and III randomized clinical trials published up to 25 October 2018. Summary incidence, relative risk and corresponding $95 \%$ Cls were calculated for grade 3-4 neutropenia. Results: Five randomized clinical trials were included. Relative risk $(95 \% \mathrm{Cl})$ of developing grade $3-4$ neutropenia with ALK inhibitor versus chemotherapy was 0.27 (0.07-1.06). Probabilities of developing grade 3-4 neutropenia were 6.56 and $14.19 \%$, respectively; no significant difference was found. Conclusion: In patients with non-small-cell lung cancer, incidence of grade 3-4 neutropenia with ALK-targeted therapy is not significantly different compared with chemotherapy.
\end{abstract}

First draft submitted: 16 November 2018; Accepted for publication: 1 May 2019; Published online: 22 May 2019

Keywords: alectinib • ALK inhibitor $\bullet$ anaplastic lymphoma kinase $\bullet$ ceritinib $\bullet$ chemotherapy $\bullet$ crizotinib $\bullet$ neutropenia • non-small-cell lung cancer $\bullet$ NSCLC • targeted therapy

Worldwide in 2018, of all diagnosed cancer types, lung cancer was the joint most commonly diagnosed cancer along with breast cancer (2 million new cases; 11.6\%) and the leading cause of cancer death with 1.8 million people dying of the disease, accounting for $18.4 \%$ of all cancer deaths [1]. Lung cancer confers a substantial burden on economies and societies [2]. In 2015, the cost of lung cancer care in the European Union (EU) amounted to $€ 18.8$ billion, representing $15 \%$ of total cancer-related costs [3]. In the US in 2010, estimated national expenditure on lung cancer care was US $\$ 12.1$ billion, rising to US $\$ 13.9$ billion in 2017 [4]. Overall, 85-90\% of lung cancers are non-small-cell lung cancers (NSCLCs) of which the most common are adenocarcinoma ( $40 \%$ of lung cancer), squamous cell carcinoma (25-30\%) and large cell carcinoma (10-15\%) [5,6]. A large proportion (40\%) of patients with NSCLC present with advanced stage disease [7].

The $A L K$ gene encodes a transmembrane receptor tyrosine kinase, which belongs to the insulin receptor superfamily, and is highly homologous to leukocyte tyrosine kinase [8]. In humans, the $A L K$ gene is located on the short arm of chromosome 2 and was originally detected as a fusion gene in patients with anaplastic large cell lymphoma [8]. Genetic changes of the $A L K$ gene, such as rearrangements, mutations and amplification, resulting in its constitutive activation have been identified and linked to the development and progression of neuroblastoma, lymphoma, breast cancer and NSCLC [8-10]. It is estimated that $3-7 \%$ of patients with NSCLC harbor rearrangements of $A L K$, termed ALK-positive NSCLC [11,12].

For patients with locally advanced or metastatic NSCLC, platinum-based chemotherapy regimens using cisplatin and carboplatin have been considered the standard of care [13,14], with the American Society of Clinical Oncology (ASCO) and the European Society for Medical Oncology (ESMO) recommending platinum-based chemotherapy doublets in patients who do not harbor $A L K$ rearrangements and have a performance status score of $0-2[15,16]$.

Future Medicine 
The National Comprehensive Cancer Network (NCCN) recommends platinum-based combinations and some single-agent chemotherapy agents, but not cisplatin-based regimens, in patients with advanced NSCLC who have a performance status score of 2 [17]. Despite this, it appears that the efficacy of strategies using platinum-based chemotherapy has somewhat plateaued, with the majority of trials not improving on overall response rates of $25-35 \%$ and overall survival of between 12 and 14 months $[17,18]$. Furthermore, most clinical studies include patients with a performance status score of 0 or 1 , thus the clinical study population likely reflects better survival compared with the real-life population [19].

Targeted therapy with crizotinib, the first-in-class ALK inhibitor with activity against multiple targets (ALK, ROS1 and MET) [20], radically changed how ALK-positive NSCLC was managed and treated [21]. Crizotinib (Xalkori ${ }^{\circledR}$, Pfizer) received approval from the US FDA for the treatment of ALK-positive NSCLC patients in August 2011 and from the European Medicines Agency (EMA) in November 2012 [22,23]. Rapid regulatory approval was based on results of Phase I and II studies, which reported durable treatment responses [24-26]. Successive Phase III studies in both previously treated (PROFILE 1007) [27] and treatment-naive (PROFILE 1014) [28] patients demonstrated that crizotinib resulted in significantly improved survival and quality of life, and had an acceptable safety profile.

However, resistance develops in the majority of patients receiving crizotinib, often within 12 months of beginning therapy [29,30]. Thus, several second-generation ALK inhibitors have become available in order to overcome acquired resistance to crizotinib, such as ceritinib (Zykadia ${ }^{\circledR}$, Novartis), alectinib (Alecensa ${ }^{\circledR}$, Roche) and brigatinib (Alunbrig ${ }^{\circledR}$, Takeda), which received US FDA approval in 2014, 2015 and 2017, respectively [31-33]. In Europe, the EMA granted approval for Zykadia ${ }^{\circledR}$ in 2015 and for Alecensa ${ }^{\circledR}$ in 2017 [34,35]. Moreover, in September 2018, Alunbrig ${ }^{\circledR}$ was awarded a positive opinion for marketing authorization from the EMA's Committee for Medicinal Products for Human Use [36]. Numerous third-generation ALK inhibitors are also in development including entrectinib (a highly active pan-Trk, ROS1 and ALK inhibitor) [37] and lorlatinib (a selective brainpenetrant ALK and ROS1 inhibitor) [38]. In patients who have developed crizotinib resistance, response rates with second-generation ALK inhibitors have been reported to be $50-55 \%$ and median progression-free survival (PFS) with ceritinib, alectinib and brigatinib are 6.9, 8.9 and 15.6 months, respectively [39-41].

A common side effect of platinum-based chemotherapy agents is neutropenia, which can result in reductions of chemotherapy dose of between 25 and 100\% [42]; however, the risk of neutropenia depends on the specific regimen used, intensity of chemotherapy, burden of disease and age of the patient [43]. Indeed, in a retrospective study, grade 3-4 neutropenia was reported in $58.3 \%(n=14)$ and grade $3-4$ febrile neutropenia $(\mathrm{FN})$ in $8.3 \%(\mathrm{n}=2)$ of patients with locally advanced NSCLC with physician's choice of platinum-based chemotherapy doublets [44]. Overall, ALK inhibitors are generally well tolerated [30,45,46]; however, there are some reports emerging of grade 3-4 neutropenia with ALK inhibitors. Therefore, this study aimed to assess and compare the incidence of grade 3-4 neutropenia among patients with ALK-positive NSCLC who received ALK inhibitors or chemotherapy.

\section{Materials \& methods}

Aim

Using the available literature, this meta-analysis aimed to compare reports of the incidence of grade 3-4 neutropenia with ALK inhibitors and chemotherapy in patients with ALK-positive NSCLC.

\section{Search strategy}

The MEDLINE and PubMed databases were searched in order to identify peer-reviewed papers published up to 25 October 2018. The search strategy included the terms 'crizotinib' OR 'alectinib' OR 'brigatinib' OR 'ceritinib' OR 'ensartinib' OR 'entrectinib' OR 'lorlatinib' OR 'ALK inhibitor' OR 'ALK tyrosine kinase inhibitor' AND 'lung cancer' AND 'chemotherapy'.

Eligible studies were limited to: randomized clinical trials (Phase II, Phase III, Phase IIIb); use of any ALK inhibitor; full publications in English; global geographic scope; NSCLC as tumor type; adequate safety profile; and comparison to either chemotherapy or another ALK inhibitor. Study inclusion was decided independently by A Krendyukov and $\mathrm{N}$ Mathieson, and any difference of opinion was resolved by consensus and/or additional evaluation by B Rapoport.

Data describing the participants, interventions and incidence of grade 3-4 neutropenia were extracted and entered into an electronic sheet, which was double-checked for correctness. 


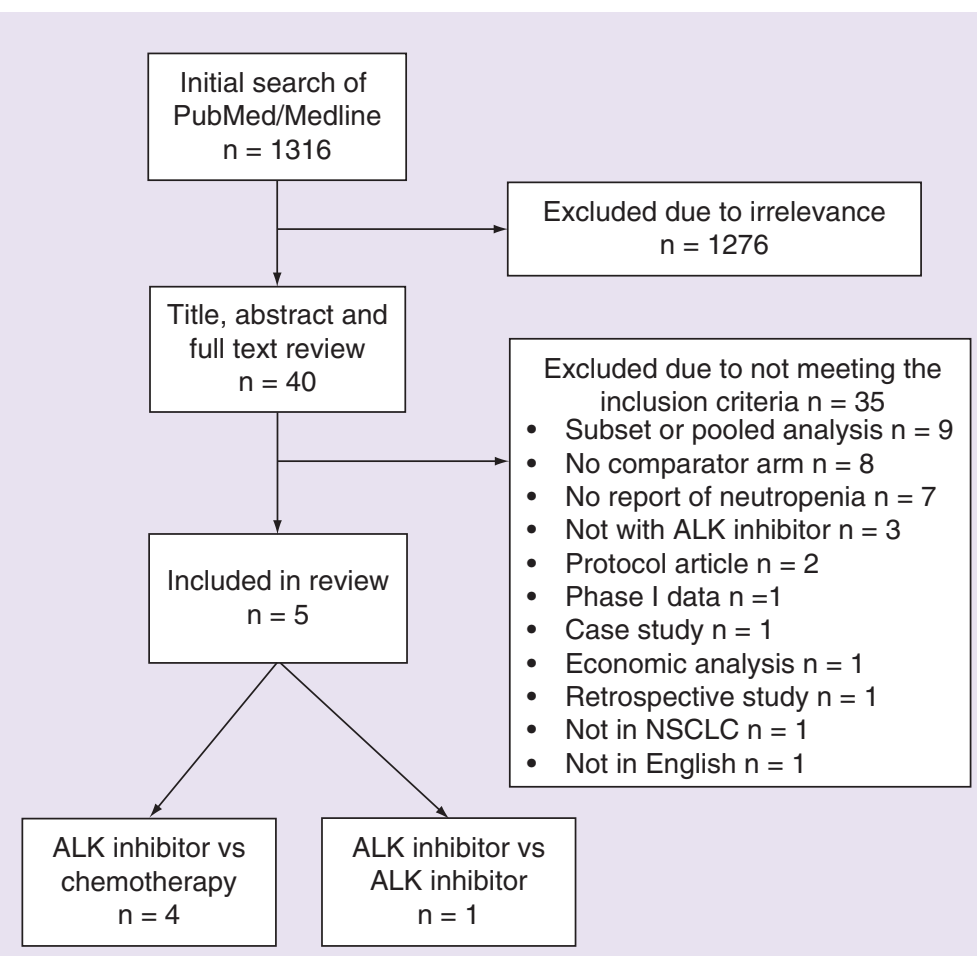

Figure 1. Search strategy.

$\mathrm{n}$ : Number of patients with characteristic; NSCLC: Non-small-cell lung cancer.

The primary end point was incidence of grade 3-4 neutropenia. If results of a study were identified in multiple publications, only the most recent reference was included. Studies were excluded if they were preclinical, performed in healthy volunteers, used granulocyte colony-stimulating factor as supportive care, did not contain a comparator arm, or were subset/pooled analyses.

\section{Statistical analysis}

Baseline characteristics were summarized using descriptive statistics. Statistical analyses were carried out to calculate the summary incidence, relative risk (RR) and corresponding $95 \%$ CIs by utilizing mixed effect models, accounting for the heterogeneity of included studies. Analyses were performed using SAS ${ }^{\circledR}$ (version 9.4) and $\mathrm{R}^{\circledR}$ (version 3.4). The impact of baseline tumor stage on treatment difference for risk of neutropenia was also assessed.

\section{Assessment of bias}

Bias of individual studies was assessed by outcome by applying Grading of Recommendations Assessment, Development and Evaluation (GRADE) criteria. Each outcome (incidence of grade 3-4 neutropenia, incidence of FN and risk of grade 3-4 neutropenia) was evaluated against the following criteria for each study: inadequate methods of sequence generation; lack of allocation concealment; lack of blinding of each of participants, providers and outcome assessors; loss to follow-up; failure to follow intention-to-treat principles in analyses; selective outcome reporting and other sources of bias (e.g., stopping the trial for benefit) [47]. Based on the limitations of the studies, an overall judgment was made on whether to downgrade the evidence.

Methods for assessment of bias of the cumulative evidence are not recommended in meta-analyses that include fewer than ten studies [48], and as such were not applied in this study.

\section{Results}

Included studies

The MEDLINE/PubMed search yielded a total of 1316 articles and of these five were eligible for inclusion (Figure 1) [27,28,49-51]. An ALK inhibitor was compared with chemotherapy in four of the studies (first-generation 
Table 1. Design of the five eligible studies comparing an ALK inhibitor with chemotherapy or another ALK inhibitor in patients with ALK-positive non-small-cell lung cancer.

\begin{tabular}{|c|c|c|c|c|c|c|}
\hline $\begin{array}{l}\text { Study (year) and } \\
\text { trial ID }\end{array}$ & Study design & Line of treatment & Arms and sample size & Total dose & Region & Ref. \\
\hline $\begin{array}{l}\text { Shaw et al. (2017) } \\
\text { (NCT01828112) }\end{array}$ & $\begin{array}{l}\text { Randomized, } \\
\text { controlled, open-label, } \\
\text { Phase III trial }\end{array}$ & Second line & $\begin{array}{l}\text { ALK inhibitor (ceritinib; } \\
n=115 \text { ) vs } \\
\text { chemotherapy } \\
\text { (pemetrexed }[n=40] \text { or } \\
\text { docetaxel }[n=73] \text { ) }\end{array}$ & $\begin{array}{l}\text { Ceritinib: oral } 750 \mathrm{mg} / \text { day fasted in } \\
\text { 21-day cycles } \\
\text { Chemotherapy: iv. pemetrexed } \\
500 \mathrm{mg} / \mathrm{m}^{2} \text { or docetaxel } 75 \mathrm{mg} / \mathrm{m}^{2} \\
\text { (investigator choice) every } 21 \text { days }\end{array}$ & $\begin{array}{l}\text { Asia, Canada, } \\
\text { Europe, Russia, US }\end{array}$ & [50] \\
\hline $\begin{array}{l}\text { Soria et al. (2017) } \\
\text { (NCT01828099) }\end{array}$ & $\begin{array}{l}\text { Randomized, } \\
\text { open-label, Phase III } \\
\text { trial }\end{array}$ & First line & $\begin{array}{l}\text { ALK inhibitor (ceritinib; } \\
n=189 \text { ) vs } \\
\text { chemotherapy } \\
\text { (pemetrexed plus } \\
\text { cisplatin [ } n=87 \text { ] or } \\
\text { carboplatin }[n=88] \text { ) }\end{array}$ & $\begin{array}{l}\text { Ceritinib: oral } 750 \mathrm{mg} / \text { day } \\
\text { Chemotherapy: iv. pemetrexed } \\
500 \mathrm{mg} / \mathrm{m}^{2} \text { plus either cisplatin } \\
75 \mathrm{mg} / \mathrm{m}^{2} \text { or carboplatin } \\
5-6 \mathrm{mg} / \mathrm{ml} / \mathrm{min} \text { every } 3 \text { weeks for up } \\
\text { to } 4 \text { cycles followed by maintenance } \\
\text { pemetrexed }\end{array}$ & $\begin{array}{l}\text { Asia, Australia, } \\
\text { Europe, New } \\
\text { Zealand, Russia, } \\
\text { South America }\end{array}$ & [51] \\
\hline $\begin{array}{l}\text { Hida et al. (2017) } \\
\text { (JapicCTI-132316) }\end{array}$ & $\begin{array}{l}\text { Randomized, } \\
\text { open-label, Phase III } \\
\text { trial }\end{array}$ & First and second line & $\begin{array}{l}\text { ALK inhibitor (alectinib } \\
n=103 \text { ) vs ALK inhibitor } \\
\text { (crizotinib } n=104 \text { ) }\end{array}$ & $\begin{array}{l}\text { Alectinib: oral } 300 \mathrm{mg} \text { twice daily } \\
\text { Crizotinib: oral } 250 \mathrm{mg} \text { twice daily }\end{array}$ & Asia (Japan) & [49] \\
\hline $\begin{array}{l}\text { Solomon et al. } \\
\text { (2014) } \\
\text { (NCT01154140) }\end{array}$ & $\begin{array}{l}\text { Randomized, } \\
\text { open-label, Phase III } \\
\text { trial }\end{array}$ & First line & $\begin{array}{l}\text { ALK inhibitor (crizotinib } \\
n=172 \text { ) vs } \\
\text { chemotherapy } \\
\text { (pemetrexed plus } \\
\text { cisplatin or carboplatin } \\
n=171 \text { ) }\end{array}$ & $\begin{array}{l}\text { Crizotinib: oral } 250 \mathrm{mg} \text { twice daily } \\
\text { Chemotherapy: iv. pemetrexed } \\
500 \mathrm{mg} / \mathrm{m}^{2} \text { plus either cisplatin } \\
75 \mathrm{mg} / \mathrm{m}^{2} \text { or carboplatin } \\
5-6 \mathrm{mg} / \mathrm{ml} / \mathrm{min} \text { every } 3 \text { weeks for up } \\
\text { to } 6 \text { cycles }\end{array}$ & $\begin{array}{l}\text { Asia, Australia, } \\
\text { Canada, Europe, } \\
\text { New Zealand, } \\
\text { Russia, South } \\
\text { America, US }\end{array}$ & [28] \\
\hline $\begin{array}{l}\text { Shaw et al. (2013) } \\
\text { (NCT00932893) }\end{array}$ & $\begin{array}{l}\text { Randomized, } \\
\text { open-label, Phase III } \\
\text { trial }\end{array}$ & Second line & $\begin{array}{l}\text { ALK inhibitor (crizotinib } \\
n=173 \text { ) vs } \\
\text { chemotherapy } \\
\text { (pemetrexed }[n=99] \text { or } \\
\text { docetaxel }[n=72] \text { ) }\end{array}$ & $\begin{array}{l}\text { Crizotinib: oral } 250 \mathrm{mg} \text { twice daily } \\
\text { Chemotherapy: iv. pemetrexed } \\
500 \mathrm{mg} / \mathrm{m}^{2} \text { or docetaxel } 75 \mathrm{mg} / \mathrm{m}^{2} \\
\text { every } 3 \text { weeks }\end{array}$ & $\begin{array}{l}\text { Asia, Australia, } \\
\text { Canada, Europe, } \\
\text { Russia, South } \\
\text { America, US }\end{array}$ & [27] \\
\hline
\end{tabular}

\section{Table 2. Baseline characteristics of patients who received either chemotherapy or an ALK inhibitor.}

\begin{tabular}{|c|c|c|}
\hline Characteristic & Patients who received chemotherapy $(\mathrm{N}=648)$ & Patients who received an ALK inhibitor $(\mathrm{N}=856)$ \\
\hline Age $<65$ years, $\mathrm{n}(\%)$ & $240(37.0 \%)$ & $395(46.1 \%)$ \\
\hline \multicolumn{3}{|l|}{ ECOG performance status, $\mathrm{n}(\%)$ : } \\
\hline$-0-1$ & $555(85.6 \%)$ & $802(93.7 \%)$ \\
\hline-2 & $38(5.9 \%)$ & $52(6.1 \%)$ \\
\hline Male, n (\%) & $269(41.5 \%)$ & $359(41.9 \%)$ \\
\hline \multicolumn{3}{|l|}{ Tumor stage, $\mathrm{n}(\%)$ : } \\
\hline - IIIb (locally advanced) & $24(3.7 \%)$ & $27(3.2 \%)$ \\
\hline - IV (metastatic) & $623(96.1 \%)$ & $778(90.9 \%)$ \\
\hline Discontinued study, n (\%) & $457(70.5 \%)$ & $440(51.4 \%)$ \\
\hline Neutropenia grade $3-4, n(\%)$ & $95(14.7 \%)$ & $60(7.0 \%)$ \\
\hline
\end{tabular}

crizotinib in two studies, second-generation ceritinib in two studies) [27,28,50,51] and the remaining study compared two ALK inhibitors (first-generation crizotinib with second-generation alectinib) (Table 1) [49].

\section{Baseline characteristics}

Across the five Phase III randomized studies, a total of 1504 patients were included. Of these, $856(57.0 \%)$ received an ALK inhibitor (crizotinib [ $\mathrm{n}=449]$, ceritinib $[\mathrm{n}=304]$ or alectinib $[\mathrm{n}=103]$ ) and $648(43.1 \%)$ received chemotherapy. The chemotherapy regimens used consisted of docetaxel alone, pemetrexed alone or pemetrexed in combination with cisplatin or carboplatin (Table 1).

The baseline characteristics of patients who received either chemotherapy or an ALK inhibitor are outlined in Table 2, and were generally similar between the groups, including age $<65$ years (37.0 vs $46.1 \%$, respectively), Eastern Cooperative Oncology Group performance score of 0-1 (85.6 vs 93.7\%), male gender (41.5 vs 41.9\%) and tumor stage (IIIb: 3.7 vs 3.2\%; V: 96.1 vs 90.9\%). However, it was noted that a smaller proportion of patients 
who received an ALK inhibitor discontinued in their respective studies $(\mathrm{n}=440 ; 51.4 \%)$ compared with patients who received chemotherapy $(n=457 ; 70.5 \%)$. Among patients who received an ALK inhibitor, reasons for study discontinuation consisted of disease progression or relapse $(n=180)$, adverse events (AEs; $n=76$ ), deterioration of health status $(n=49)$, lack of efficacy $(n=46)$, death $(n=36)$, withdrawal of consent by patient/guardian $(n=28)$, physician decision $(n=5)$ and other $(n=20)$. Three patients who received chemotherapy discontinued before receiving treatment; reasons for the remaining 454 discontinuations were disease progression or relapse $(\mathrm{n}=286)$, AEs $(n=56)$, deterioration of health status $(n=29)$, withdrawal of consent by patient/guardian $(n=29)$, death $(\mathrm{n}=23)$, physician decision $(\mathrm{n}=3)$ and other $(\mathrm{n}=28)$. None of the studies excluded patients based on smoking status.

\section{Incidence of grade 3-4 neutropenia}

Overall, grade 3-4 neutropenia was reported in $14.7 \%(\mathrm{n}=95)$ of patients who received chemotherapy and in $7.0 \%(n=60)$ of patients who received an ALK inhibitor (Table 2).

In the study comparing first- and second-generation ALK inhibitors in patients who had not received chemotherapy or had only received one prior line of chemotherapy, neutrophil count decrease (all grades) was reported in 19 $(18.3 \%)$ patients in the crizotinib arm and in three (2.9\%) patients in the alectinib arm [49]. Grade 3-4 neutrophil count decrease was reported in $14(13.5 \%)$ and two (1.9\%) patients with crizotinib and alectinib, respectively [49].

Incidence of any grade and grade 3-4 neutropenia was always lower with ALK inhibitor treatment compared with chemotherapy $[27,28,50,51]$. The earliest of the included studies compared the first-generation ALK inhibitor crizotinib with chemotherapy in previously treated patients and reported grade 3-4 neutropenia in $13.3 \%(\mathrm{n}=23)$ and $18.9 \%(\mathrm{n}=33)$ of patients, respectively [27]. In the second study making this treatment comparison but in previously untreated patients, neutropenia of any grade occurred in $20.9 \%(\mathrm{n}=36)$ of patients receiving crizotinib and $29.8 \%(\mathrm{n}=51)$ of patients receiving chemotherapy [28]. Grade 3-4 neutropenia was reported in $11.0 \%$ $(\mathrm{n}=19)$ and $15.2 \%(\mathrm{n}=26)$ of patients in the crizotinib and chemotherapy arms, respectively [28]. In the two studies comparing the second-generation ALK inhibitor ceritinib with chemotherapy, one reported the incidence of grade $1-2$ and grade $3-4$ neutropenia as $2.6 \%(n=3)$ and $0.9 \%(n=1)$ with ceritinib and $5.2 \%(n=6)$ and $14.7 \%(\mathrm{n}=17)$ with chemotherapy, respectively, in patients who had progressed after receiving crizotinib and a platinum-based chemotherapy doublet [50]. The second study, performed in previously untreated patients, reported neutropenia of any grade in $4.8 \%(n=9)$ of patients who received ceritinib and $20.3 \%(n=38)$ who received chemotherapy [51]. Incidence of any grade 3-4 neutropenia was $0.5 \%(n=1)$ with ceritinib and $10.2 \%(n=19)$ with chemotherapy [51].

\section{Incidence of FN}

Incidence of FN was reported in three of the five studies and in all instances was lower with ALK inhibitor therapy than with chemotherapy $[27,28,50]$. When comparing first-generation ALK inhibitor crizotinib with chemotherapy, one study reported grade $3-4 \mathrm{FN}$ in one patient $(0.6 \%)$ treated with crizotinib and in 16 patients $(9.2 \%)$ treated with chemotherapy [27]. Solomon et al. reported no incidence of FN with crizotinib and two cases (11.7\%) of FN with chemotherapy [28]. Incidence of FN was reported in one study comparing chemotherapy with a second-generation ALK inhibitor, finding no incidence of FN with ceritinib and one patient $(0.9 \%)$ who received chemotherapy experienced grade $3 \mathrm{FN}$ [50].

\section{Risk of grade 3-4 neutropenia}

A nonlinear mixed effect model was considered, assuming the study effect and treatment effect to be random effect and fixed effect, respectively. The RR of developing grade 3-4 neutropenia with ALK inhibitor therapy compared with chemotherapy was 0.27 (95\% CI: 0.07-1.06; Figure 2). The probability of grade 3-4 neutropenia in patients who received chemotherapy was $14.19 \%$ and in patients who received an ALK inhibitor was 6.56\% (Table 3). Of note, the $95 \%$ CIs overlap for the two treatment arms and thus it can be concluded that the difference in probability of grade 3-4 neutropenia between the two treatment arms is not significant at the 5\% level of significance. Furthermore, it was observed that impact of baseline tumor stage on treatment difference is not significant (Table 4). Despite the treatment difference being nonsignificant, the trend in treatment difference across the studies favors ALK inhibitor therapy. 


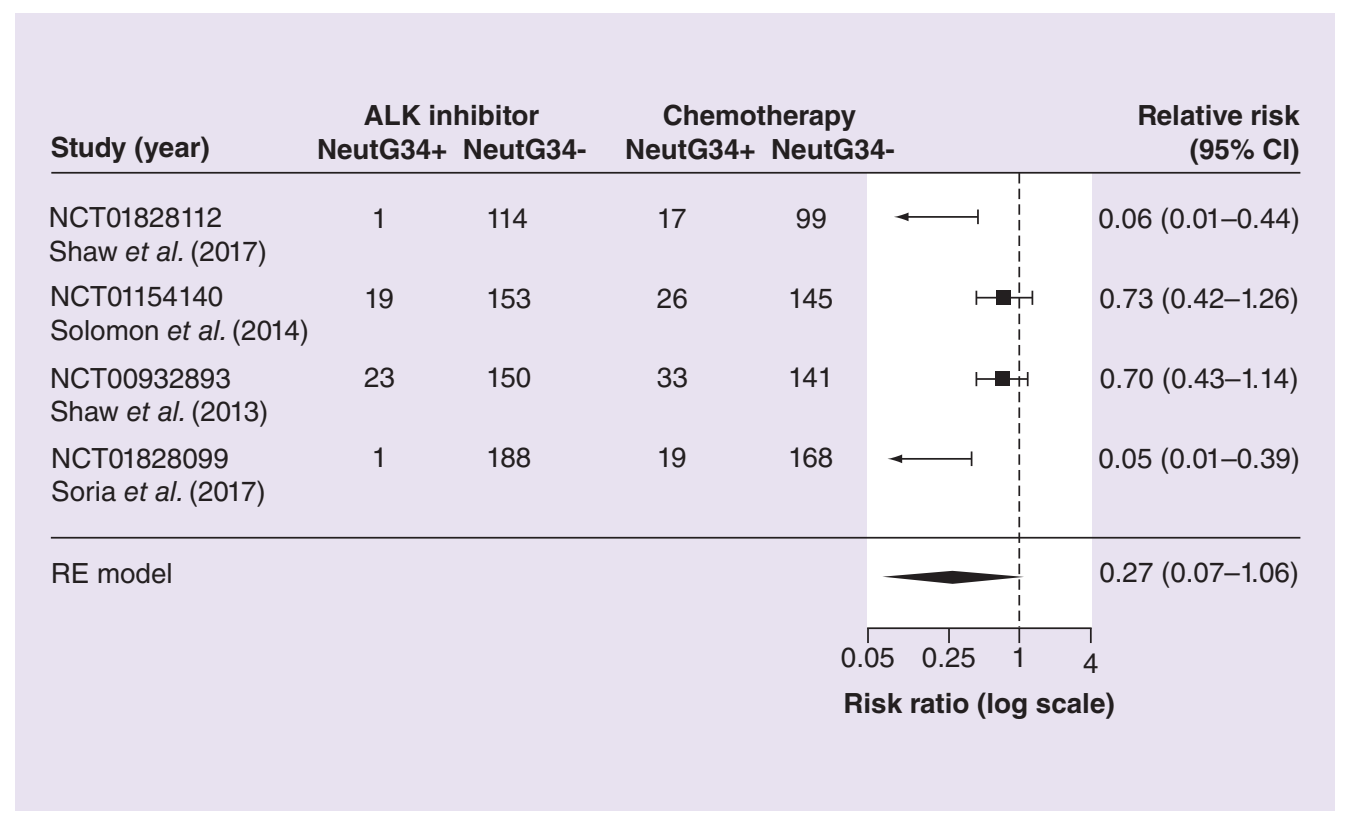

Figure 2. Grade 3-4 neutropenia in patients with non-small-cell lung cancer who received chemotherapy or ALK inhibitor. One study [49] is not shown due to comparing two different ALK inhibitors and not comparing to chemotherapy.

NeutG34+: Number of patients reported to experience grade 3-4 neutropenia; NeutG34 : Number of patients reported not to experience grade 3-4 neutropenia; RE: Random effect.

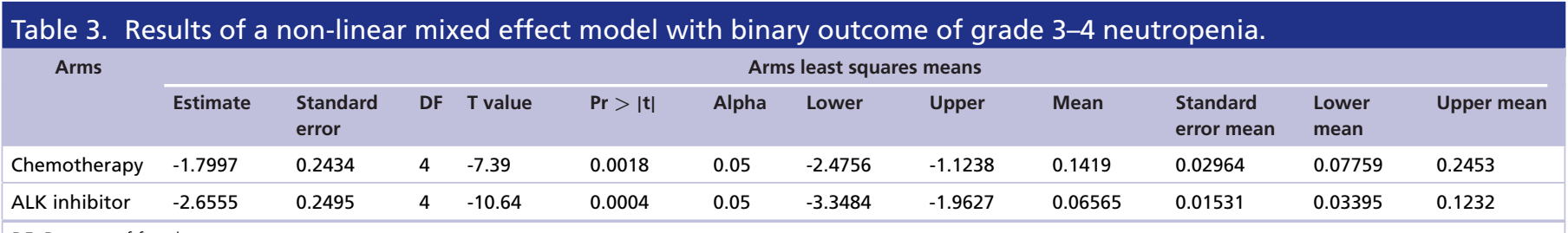

DF: Degrees of freedom.

Table 4. Results of a non-linear mixed effect model with binary outcome of grade 3-4 neutropenia adjusting for tumor stage.

\begin{tabular}{|c|c|c|c|c|c|c|c|c|c|c|c|c|}
\hline \multirow[t]{2}{*}{ Arms } & \multicolumn{12}{|c|}{ Arms least squares means } \\
\hline & Estimate & $\begin{array}{l}\text { Standard } \\
\text { error }\end{array}$ & DF & $\mathrm{T}$ value & $\operatorname{Pr}>|t|$ & Alpha & Lower & Upper & Mean & $\begin{array}{l}\text { Standard } \\
\text { error mean }\end{array}$ & $\begin{array}{l}\text { Lower } \\
\text { mean }\end{array}$ & Upper mean \\
\hline Chemotherapy & -1.8021 & 0.2745 & 3 & -6.57 & 0.0072 & 0.05 & -2.6757 & -0.9286 & 0.1416 & 0.03336 & 0.06442 & 0.2832 \\
\hline ALK inhibitor & -2.6614 & 0.2792 & 3 & -9.53 & 0.0024 & 0.05 & -3.5499 & -1.7729 & 0.06529 & 0.01704 & 0.02793 & 0.1452 \\
\hline
\end{tabular}

\section{Assessment of bias}

For each of the three outcomes (incidence of grade 3-4 neutropenia, incidence of FN and risk of grade 3-4 neutropenia), the overall assessment was that most information was from studies at low risk of bias, and as such, there was no serious risk of bias and the evidence was not downgraded (Supplementary Tables 1-3).

\section{Discussion}

Neutropenia and FN can be serious, life-threatening side effects of myelosuppressive chemotherapy that often bring about hospitalization and dose reductions or delays [52]. Dose modifications, such as reductions and delays, with numerous chemotherapy regimens to treat a range of cancer types have been associated with shorter survival [53-58]. 
In patients with solid tumors (including NSCLC) and hematological malignancies receiving myelosuppressive chemotherapy, current guidelines recommend prophylaxis of severe neutropenia and FN in those considered at risk $[43,59,60]$. Antimicrobials such as fluoroquinolones used to be a common approach to prevent FN in patients receiving chemotherapy, which achieved some relative success [43]. However, use of antimicrobials is not recommended due to the emergence of resistant strains [43].

Various guidelines, including those issued by ASCO, ESMO and the NCCN, recommend the use of myeloid growth factors, such as granulocyte colony-stimulating factors, as an adjunct to chemotherapy in order to prevent FN $[43,59,60]$. Primary prophylaxis is recommended to support regimens which carry a $\geq 20 \%$ risk of FN and for those which carry a $10-20 \%$ risk if the patients also display other risk factors such as older age ( $\geq 65$ years), advanced disease, poor performance status, cardiovascular disease, poor liver/renal function or a previous history of FN [43,59,60]. In one retrospective study of 270 patients with lung cancer treated with systemic chemotherapy, $17 \%$ $(n=46)$ of patients developed FN for the duration of chemotherapy, and chronic obstructive pulmonary disease was significantly associated with an increased risk of FN (odds ratio [OR]: 2.5; 95\% CI: 1.16-5.38; p = 0.02) [61]. In addition, in another retrospective analysis of 244 patients with lung cancer receiving systemic therapy with etoposide plus platinum-based chemotherapy (cisplatin, $n=88$; carboplatin, $n=156$ ), grade $3-4$ neutropenia was reported in $85.2 \%(n=208)$ of patients and the multivariate analysis identified prior radiotherapy and male gender as independent risk factors for FN [62]. Real-world evidence is more limited, however, evidence from patients with other tumor types suggests that neutropenia rates in the real-world setting may be higher than those in clinical trials [63].

Prophylaxis appears to be an effective strategy of managing neutropenia and FN in patients with lung cancer. In a retrospective analysis of 11,233 adult patients with lung cancer receiving chemotherapy with a low to intermediate risk of neutropenia-related hospitalization, patients who had received primary prophylaxis with granulocyte colonystimulating factor were less likely to experience neutropenia-related hospitalization compared with patients who had not received prophylaxis (4.7 vs 7.5\%; OR: 0.61; 95\% CI: 0.49-0.74) [64].

The reported incidence of neutropenia with targeted treatments for cancer therapy is currently limited; however, evidence of grade 3-4 neutropenia with ALK inhibitors is starting to emerge. In a pooled safety analysis, which included 17 trials published from 2011 to 2016 and over 1800 patients with ALK-positive NSCLC, a significantly higher incidence of grade $\geq 3$ neutropenia was observed among patients treated with the first-generation inhibitor crizotinib (6.7\%) than those treated with the second-generation inhibitors ceritinib $(0.0 \%$; OR: 0.03 ; $95 \%$ CI: 0.01-0.44; $\mathrm{p}<0.001)$ and alectinib (1.1\%; OR: 6.20; 95\% CI: 0.85-45.41; $\mathrm{p}=0.040)$ [65]. At present, information regarding the real-world clinical experience and management of neutropenia and FN with targeted treatments is also limited and myeloid growth factor use is not recommended by ASCO, ESMO or the NCCN as an adjunct to these agents in order to reduce the risk and incidence of FN $[43,59,60]$.

In addition, the effect of dose reductions and delays with ALK inhibitor therapy, as well as other targeted treatments, on the survival of patients with cancer is thus far unknown. Although a case report of a patient receiving an ALK inhibitor has been published where neutropenia was successfully managed via dose reduction [66]. The patient was a 53-year-old female with ALK-positive NSCLC receiving third-line crizotinib at $500 \mathrm{mg} /$ day orally. A partial response was achieved after 4 weeks of crizotinib therapy; however, at 8 weeks a drop in neutrophil count was noted which progressed to grade 4 neutropenia by week 36. Dose reduction of crizotinib from 500 to $250 \mathrm{mg} / \mathrm{day}$ by week 51 resulted in correction of grade 4 neutropenia and permitted crizotinib therapy to be continued for 20 weeks. According to the authors of the case study, this was the first report of managing neutropenia induced by ALK inhibitor therapy using dose reduction, and they emphasize that further real-world clinical experience is needed in order to improve and align the management of neutropenia, and other AEs, in patients receiving these agents [66].

Our study aimed to compare the reported incidence of grade 3-4 neutropenia with ALK inhibitors and chemotherapy in patients with ALK-positive NSCLC using the currently available literature. Five Phase III randomized studies enrolling a total of 1504 patients met our eligibility criteria, with four studies comparing an ALK inhibitor with chemotherapy [27,28,50,51] and the fifth study comparing first- and second-generation ALK inhibitors [49].

Across the five studies, the incidence of grade 3-4 neutropenia was $14.7 \%(\mathrm{n}=95)$ among patients who were administered chemotherapy and only $7.0 \%(\mathrm{n}=60)$ among those who were administered ALK inhibitor therapy with either crizotinib, ceritinib or alectinib. In our nonlinear mixed effect model, the RR (95\% CI) of developing grade 3-4 neutropenia with ALK inhibitor therapy compared with chemotherapy was $0.27(0.07-1.06)$ and the 
probabilities of developing grade 3-4 neutropenia were 6.56 and $14.19 \%$, respectively, but the difference was not significant. The present study suggests that the difference in the incidence of severe neutropenia between patients receiving ALK inhibitors and those receiving chemotherapy is not significant. However, evidence in this systematic review is limited, with only five studies meeting the inclusion criteria, and only four of which compared ALK inhibitor therapy with chemotherapy, thus further studies are required. Moreover, there are limitations of comparing the incidence of AEs, such as neutropenia and FN, between different clinical trials as there may be differences in how events are defined, reported and recorded, as well as differences in patient populations, treatment regimens, inclusion and exclusion criteria, and clinical settings [67-69].

In all four studies comparing an ALK inhibitor to chemotherapy, a significant improvement in median PFS was observed with the ALK inhibitor and response rates ranged from 39 to $74 \%$ with ALK inhibitor therapy versus $7-45 \%$ with chemotherapy $[27,28,50,51]$. Across these studies, the majority of AEs were grade 1-2 in severity in both treatment groups, and the most common AEs of any grade with ALK inhibitor therapy were gastrointestinal side effects, vision disorders, edema and elevated liver aminotransferase levels. With chemotherapy, these consisted of fatigue, anemia, nausea, vomiting, alopecia and dyspnea [27,28,50,51]. Overall, the results of these four studies demonstrate that therapy with an ALK inhibitor lengthens PFS, improves overall survival and increases response rates, while having an acceptable toxicity profile, compared with chemotherapy in both treatment-naive and previously treated patients with ALK-positive NSCLC [27,28,50,51].

The remaining study in this meta-analysis compared two different ALK inhibitors and found that alectinib is better tolerated and significantly improves PFS compared with crizotinib (not estimable vs 10.2 months; hazard ratio: 0.34 ; 99.7\% CI: $0.17-0.71 ; \mathrm{p}<0.0001$ ) in the treatment of ALK-positive NSCLC patients who had previously not received chemotherapy or only one previous line of chemotherapy [47].

Generally, with each new generation, ALK inhibitors increase in potency and selectivity. Several third-generation ALK inhibitors are currently under development, such as entrectinib, which has been assessed in two Phase I dose escalation trials (ALKA-372-001 and STARTRK-1) [70] and one Phase II trial (STARTRK-2; NCT02568267). In an integrated analysis of these three studies, in patients with locally advanced or metastatic ROS1-positive NSCLC, objective response rate was $77.4 \%$, duration of response was 24.6 months (95\% CI: $11.4-34.8$ ) and median PFS was 19.0 months (95\% CI: 12.2-36.6) [71]. The majority of treatment-related AEs were grade 1-2 and reversible, with the most common being dysgeusia (41.4\%), fatigue (27.9\%), dizziness (25.4\%), constipation (23.7\%), diarrhea $(22.8 \%)$ and nausea $(20.8 \%)$ [71]. Roche plans to submit these data to global health authorities, including the FDA and the EMA [72].

Additionally, in the first-in-human Phase I trial of lorlatinib in patients with ALK-positive or ROS1-positive NSCLC, objective response was 46\% overall (95\% CI: 31-63\%) and 42\% among patients who had received two or more tyrosine kinase inhibitors (95\% CI: 23-63\%) [73]. The most common treatment-related AEs were hypercholesterolemia (72\%), hypertriglyceridemia (39\%), peripheral neuropathy (39\%) and peripheral edema (39\%) [73]. These results indicate that lorlatinib may be effective in patients with NSCLC who have become resistant to currently available first- and second-generation ALK inhibitors. Lorlatinib is being compared to crizotinib as first-line therapy for patients with ALK-positive NSCLC in an ongoing Phase III randomized clinical trial (NCT03052608). In early 2018, the EMA accepted the marketing application for lorlatinib, also used for ROS-1-positive NSCLC. This third-generation ALK inhibitor was also accepted for priority review by the FDA [74].

\section{Conclusion}

This meta-analysis of Phase III randomized clinical trials found no significant difference in the incidence of grade 3-4 neutropenia among patients with ALK-positive NSCLC treated with either an ALK inhibitor or chemotherapy, and this was not affected by adjusting for baseline tumor stage.

Supplementary data

To view the supplementary data that accompany this paper please visit the journal website at: www.futuremedicine.com/doi/sup $\mathrm{pl} / 10.2217 /$ fon-2018-0863

Financial \& competing interests disclosure

This meta-analysis was funded by Hexal AG, Holzkirchen, Germany. B Rapoport has received grants from Sandoz, personal fees from Amgen South Africa, Roche Malaysia, Teva and Cipla South Africa. R Arani is an employee of Sandoz Inc; N Mathieson is an employee of Hexal AG. A Krendyukov was an employee of Hexal AG at the time of manuscript development. Final approval 
of the manuscript rested solely with the scientific authors. The authors have no other relevant affiliations or financial involvement with any organization or entity with a financial interest in or financial conflict with the subject matter or materials discussed in the manuscript apart from those disclosed.

Writing assistance was provided by Terri Penfold of Spirit Medical Communications Ltd, supported by Hexal AG.

\section{Data deposition}

Data from previously published reports were used in this analysis and can be found online using the PubMed/Medline and clinicaltrials.gov databases: Shaw et al. (2013; www.ncbi.nlm.nih.gov/pubmed/23724913; PMID: 23724913; clinical trial number: NCT00932893); Solomon et al. (2014; www.ncbi.nlm.nih.gov/pubmed/26466011; PMID: 26466011; clinical trial number: NCT01154140); Hida et al. (2017; www.ncbi.nlm.nih.gov/pubmed/28501140; PMID: 28501140; clinical trial number: JapicCTI132316); Soria et al. (2017; www.ncbi.nlm.nih.gov/pubmed/28126333; PMID: 28126333; clinical trial number: NCT01828099); Shaw et al. (2017; www.ncbi.nlm.nih.gov/pubmed/28602779; PMID: 28602779; clinical trial number: NCT01828112).

Open access

This work is licensed under the Attribution-NonCommercial-NoDerivatives 4.0 Unported License. To view a copy of this license, visit http://creativecommons.org/licenses/by-nc-nd/4.0/

\section{Executive summary}

\section{Background}

- For patients with locally advanced or metastatic non-small-cell lung cancer (NSCLC), platinum-based chemotherapy regimens have been considered the standard of care.

- However, the efficacy of these regimens seems to have plateaued and they have also been shown to be limited by neutropenic complications.

- Targeted therapy with ALK inhibitors radically changed how ALK-positive NSCLC (approximately 3-7\% of NSCLCS) is managed and treated.

- ALK inhibitors are generally well tolerated; however, some reports are emerging of grade 3-4 neutropenia with ALK inhibitors.

- The role of granulocyte colony-stimulating factors in the treatment of neutropenia associated with ALK inhibitors is unknown.

Materials \& methods

- This study aimed to compare the incidence of grade 3-4 neutropenia among patients with ALK-positive NSCLC who have received ALK inhibitors or chemotherapy.

- The literature search identified five eligible randomized clinical trials for inclusion: four compared an ALK inhibitor with chemotherapy and one compared two ALK inhibitors.

Results

- The relative risk of developing grade 3-4 neutropenia with ALK inhibitor therapy compared with chemotherapy was 0.27 (95\% Cl: 0.07-1.06).

- The probabilities of grade 3-4 neutropenia with ALK inhibitor compared with chemotherapy were 6.56 and $14.19 \%$, respectively.

Conclusion

- No significant difference between ALK inhibitor and chemotherapy was found in terms of incidence of grade 3-4 neutropenia; this was not affected by adjusting for baseline tumor stage.

\section{References}

Papers of special note have been highlighted as: $\bullet$ of interest; $\bullet \bullet$ of considerable interest

1. WHO International Agency for Research on Cancer. Lung cancer fact sheet. (2018). http://gco.iarc.fr/today/data/factsheets/cancers/15-Lung-fact-sheet.pdf

2. Wood R, Taylor-Stokes G. Cost burden associated with advanced non-small cell lung cancer in Europe and influence of disease stage. BMC Cancer 19(1), 214 (2019).

3. EURACTIV. Disparities remain on how to tackle lung cancer in Europe, report says. (2018). www.euractiv.com/section/diabetes-cancer-hepatitis/news/disparities-remain-on-how-to-tackle-lung-cancer-in-europe-report-says/

4. National Cancer Institute. Financial burden of cancer care. (2018). https://progressreport.cancer.gov/after/economic_burden

5. Grapatsas K, Leivaditis V, Tsilogianni Z et al. Epidemiology, risk factors, symptomatology, TNM classification of non small cell lung cancer. An overview while waiting the 8th TNM classification. Oncomedicine 2, 14-23 (2017). 
6. Zhao Z, Verma V, Zhang M. Anaplastic lymphoma kinase: role in cancer and therapy perspective. Cancer Biol. Ther. 16(12), 1691-1701 (2015).

7. Robbins RA, Kummet T. First-line therapy for non-small cell lung cancer including targeted therapy: a brief review. Southwest J. Pulm. Crit. Care. 16(3), 157-167 (2018).

8. Della Corte CM, Viscardi G, Di Liello R et al. Role and targeting of anaplastic lymphoma kinase in cancer. Mol. Cancer 17(1), 30 (2018).

9. Holla VR, Elamin YY, Bailey AM et al. ALK: a tyrosine kinase target for cancer therapy. Cold Spring Harb. Mol. Case. Stud. 3(1), a001115 (2017).

10. Hanna MG, Najfeld V, Irie HY et al. Analysis of ALK gene in 133 patients with breast cancer revealed polysomy of chromosome 2 and no ALK amplification. Springerplus 4, 439 (2015).

11. Mamdani H, Jalal SI. Spotlight on the treatment of ALK-rearranged non-small-cell lung cancer. Lung Cancer Manag. 6(4), 125-128 (2018).

12. Ziogas DC, Tsiara A, Tsironis G et al. Treating ALK-positive non-small cell lung cancer. Ann. Transl. Med. 6(8), 141 (2018).

13. Rossi A, Di Maio M. Platinum-based chemotherapy in advanced non-small-cell lung cancer: optimal number of treatment cycles. Expert Rev. Anticancer Ther. 16(6), 653-660 (2016).

14. Kuribayashi K, Funaguchi N, Nakano T. Chemotherapy for advanced non-small cell lung cancer with a focus on squamous cell carcinoma. J. Cancer Res. Ther. 12(2), 528-534 (2016).

15. Hanna N, Johnson D, Temin S et al. Systemic therapy for stage IV non-small-cell lung cancer: American Society of Clinical Oncology clinical practice guideline update. J. Clin. Oncol. 35(30), 3484-3515 (2017).

- The latest guidance and evidence-based recommendations from the American Society of Clinical Oncology (ASCO) on systemic therapy for stage IV non-small-cell lung cancer (NSCLC).

16. Planchard D, Popat S, Kerr K et al. Metastatic non-small-cell lung cancer: ESMO clinical practice guidelines for diagnosis, treatment and follow-up. Ann. Oncol. 29(Suppl. 4), iv192-iv237 (2018).

- The latest guidance and evidence-based recommendations for diagnosis, treatment and follow-up for metastatic NSCLC from the European Society for Medical Oncology (ESMO).

17. National Comprehensive Cancer Network. Clinical practice guidelines in oncology: non-small cell lung cancer. Version 1.2019 (2018). www.nccn.org/professionals/physician_gls/default.aspx\#nscl

- The latest clinical practice guidelines on NSCLC from the National Comprehensive Cancer Network.

18. Baxevanos P, Mountzios G. Novel chemotherapy regimens for advanced lung cancer: have we reached a plateau? Ann. Transl. Med. 6(8), 139 (2018).

19. West HJ, Jin JO. Performance status in patients with cancer. JAMA Oncol. 1(7), 998 (2015).

20. Sgambato A, Casaluce F, Maione P, Gridelli C. Targeted therapies in non-small cell lung cancer: a focus on ALK/ROS1 tyrosine kinase inhibitors. Expert Rev. Anticancer Ther. 18(1), 71-80 (2018).

21. Blackhall F, Cappuzzo F. Crizotinib: from discovery to accelerated development to front-line treatment. Ann. Oncol. 27(Suppl. 3), iii35-iii41 (2016).

22. Kazandjian D, Blumenthal GM, Chen HY et al. FDA approval summary: crizotinib for the treatment of metastatic non-small cell lung cancer with anaplastic lymphoma kinase rearrangements. Oncologist 19(10), e5-e11 (2014).

23. Giroux-Leprieur E, Fallet V, Cadranel J, Wislez M. Spotlight on crizotinib in the first-line treatment of ALK-positive advanced non-small-cell lung cancer: patients selection and perspectives. Lung Cancer (Auckl.) 7, 83-90 (2016).

24. Kwak EL, Bang YJ, Camidge DR et al. Anaplastic lymphoma kinase inhibition in non-small-cell-lung cancer. N. Engl. J. Med. 363(18), 1693-1703 (2010).

25. Camidge DR, Bang YJ, Kwak EL et al. Activity and safety of crizotinib in patients with ALK-positive non-small-cell lung cancer: updated results from a Phase 1 study. Lancet Oncol. 13(10), 1011-1019 (2014).

26. Kim W, Ahn M-J, Shi Y et al. Results of a global Phase II study with crizotinib in advanced ALK-positive non-small cell lung cancer. J. Clin. Oncol. 30(Suppl. 15), 7533 (2012).

27. Shaw AT, Kim DW, Nakagawa K et al. Crizotinib versus chemotherapy in advanced ALK-positive lung cancer. N. Engl. J. Med. 368(25), 2385-2394 (2013).

-. Results of a randomized, open-label, Phase III trial crizotinib with chemotherapy (pemetrexed or docetaxel) in previously treated patients with ALK-positive NSCLC.

28. Solomon BJ, Mok T, Kim DW et al. First-line crizotinib versus chemotherapy in ALK-positive lung cancer. N. Engl. J. Med. 371(23), 2167-2177 (2014).

-• Results of a randomized, open-label, Phase III trial comparing crizotinib with chemotherapy (pemetrexed plus cisplatin or carboplatin) in previously untreated patients with ALK-positive NSCLC.

29. Du X, Shao Y, Qin HF et al. ALK-rearrangement in non-small-cell lung cancer (NSCLC). Thorac. Cancer 9(4), 423-430 (2018). 
30. Li G, Dai WR, Shao FC. Effect of ALK-inhibitors in the treatment of non-small cell lung cancer: a systematic review and meta-analysis. Eur. Rev. Med. Pharmacol. Sci. 21(15), 3496-3503 (2017).

31. Bedi S, Khan SA, Abukhader MM et al. A comprehensive review on brigatinib - a wonder drug for targeted cancer therapy in non-small cell lung cancer. Saudi. Pharm. J. 26(6), 755-763 (2018).

32. Khozin S, Blumenthal GM, Zhang L et al. FDA approval: ceritinib for the treatment of metastatic anaplastic lymphoma kinase-positive non-small cell lung cancer. Clin. Cancer Res. 21(11), 2436-2439 (2015).

33. Larkins $\mathrm{E}$, Blumenthal GM, Chen $\mathrm{H}$ et al. FDA approval: alectinib for the treatment of metastatic, ALK-positive non-small cell lung cancer following crizotinib. Clin. Cancer Res. 22(21), 5171-5176 (2016).

34. European Medicines Agency. Alecensa (alectinib) authorisation details. (2018). www.ema.europa.eu/medicines/human/EPAR/alecensa

35. European Medicines Agency. Zykadia (ceritinib) authorisation details. (2018). www.ema.europa.eu/medicines/human/EPAR/zykadia

36. European Medicines Agency. Alunbrig (brigatinib) summary of opinion (initial authorisation). (2018). www.ema.europa.eu/documents/smop-initial/chmp-summary-positive-opinion-alunbrig_en.pdf

37. Drilon A, De Braud FG, Siena S et al. Entrectinib, an oral pan-Trk, ROS1, and ALK inhibitor in TKI-naïve patients with advanced solid tumors harboring gene rearrangements: updated Phase I results. Presented at: 107th Annual Meeting of the American Association for Cancer Research. New Orleans, LA, USA, 16-20 April 2016.

38. Solomon BJ, Bauer TM, Felip E et al. Safety and efficacy of lorlatinib (PF-06463922) from the dose-escalation component of a study in patients with advanced ALK+ or ROS1+ non-small cell lung cancer (NSCLC). J. Clin. Oncol. 34(Suppl. 15), 9009 (2016).

39. Kim DW, Mehra R, Tan DSW et al. Activity and safety of ceritinib in patients with ALK-rearranged non-small-cell lung cancer (ASCEND-1): updated results from the multicentre, open-label, Phase 1 trial. Lancet Oncol. 17(4), 452-463 (2016).

40. Kim DW, Tiseo M, Ahn MJ et al. Brigatinib in patients with crizotinib-refractory anaplastic lymphoma kinase-positive non-small-cell lung cancer: a randomized, multicenter Phase II trial. J. Clin. Oncol. 35(22), 2490-2498 (2017).

41. Ou SH, Ahn JS, De Petris L et al. Alectinib in crizotinib-refractory ALK-rearranged non-small-cell lung cancer: a Phase II global study. J. Clin. Oncol. 34(7), 661-668 (2016).

42. Oun R, Moussa YE, Wheate NJ. The side effects of platinum-based chemotherapy drugs: a review for chemists. Dalton Trans. 47(19), 6645-6653 (2018).

43. Klastersky J, De Naurois J, Rolston K et al. Management of febrile neutropaenia: ESMO Clinical Practice Guidelines. Ann. Oncol. 27(Suppl. 5), v111-v118 (2016).

44. Imai $\mathrm{H}$, Kaira K, Mori $\mathrm{K}$ et al. Comparison of platinum combination re-challenge therapy and docetaxel monotherapy in non-small cell lung cancer patients previously treated with platinum-based chemoradiotherapy. Springerplus 4, 152 (2015).

45. Awad MM, Shaw AT. ALK inhibitors in non-small cell lung cancer: crizotinib and beyond. Clin. Adv. Hematol. Oncol. 12(7), 429-439 (2014).

46. Rothenstein JM, Letarte N. Managing treatment-related adverse events associated with Alk inhibitors. Curr. Oncol. 21(1), 19-26 (2014).

47. Ryan R, Hill S. How to GRADE the quality of the evidence. Version 3.0. (2016). Cochrane Consumers and Communication Group. http://cccrg.cochrane.org/author-resources

48. Song F, Hooper L, Loke YK. Publication bias: what is it? How do we measure it? How do we avoid it? Open Access J. Clin. Trials 5 , 71-81 (2013)

49. Hida T, Nokihara H, Kondo M et al. Alectinib versus crizotinib in patients with ALK-positive non-small-cell lung cancer (J-ALEX): an open-label, randomised Phase 3 trial. Lancet 390(10089), 29-39 (2017).

-• Results of an open-label, randomized, Phase III trial comparing crizotinib with alectinib in patients with ALK-positive NSCLC.

50. Shaw AT, Kim TM, Crinò L et al. Ceritinib versus chemotherapy in patients with ALK-rearranged non-small-cell lung cancer previously given chemotherapy and crizotinib (ASCEND-5): a randomised, controlled, open-label, Phase 3 trial. Lancet Oncol. 18(7), 874-886 (2017).

-• Results of a randomized, open-label, Phase III trial comparing ceritinib with chemotherapy (pemetrexed or docetaxel) in patients with previously treated ALK-positive NSCLC.

51. Soria JC, Tan DSW, Chiari R et al. First-line ceritinib versus platinum-based chemotherapy in advanced ALK-rearranged non-small-cell lung cancer (ASCEND-4): a randomised, open-label, Phase 3 study. Lancet 389(10072), 917-929 (2017).

-• Results of a randomized, open-label, Phase III trial comparing ceritinib with chemotherapy (pemetrexed plus cisplatin or carboplatin) for previously untreated ALK-positive NSCLC.

52. Family L, Yang S-J, Klippel Z et al. Risk of febrile neutropenia (FN) in select myelosuppressive chemotherapy regimens. Blood 126, 3257 (2015).

53. Havrilesky LJ, Reiner M, Morrow PK et al. A review of relative dose intensity and survival in patients with metastatic solid tumors. Crit. Rev. Oncol. Hematol. 93(3), 203-210 (2015).

54. Liutkauskiene S, Grizas S, Jureniene K et al. Retrospective analysis of the impact of anthracycline dose reduction and chemotherapy delays on the outcomes of early breast cancer molecular subtypes. BMC Cancer 18(1), 453 (2018). 
55. Liutkauskiene $\mathrm{S}$, Janciauskiene $\mathrm{R}$, Jureniene $\mathrm{K}$ et al. Retrospective analysis of the impact of platinum dose reduction and chemotherapy delays on the outcomes of stage III ovarian cancer patients. BMC Cancer 15, 105 (2015).

56. Aspinall SL, Good CB, Zhao X et al. Adjuvant chemotherapy for stage III colon cancer: relative dose intensity and survival among veterans. BMC Cancer 15, 62 (2015).

57. Ramsden K, Laskin J, Ho C. Adjuvant chemotherapy in resected stage II non-small cell lung cancer: evaluation the impact of dose intensity and time of treatment. Clin. Oncol. (R. Coll. Radiol.) 27(7), 394-400 (2015).

58. Gutiérrez A, Bento L, Bautista-Gili AM et al. Differential impact of relative-dose intensity reductions in diffuse large B-cell lymphoma treated with R-CHOP21 or R-CHOP14. PLoS ONE 10(4), e0123978 (2015).

59. National Comprehensive Cancer Network. Clinical practice guidelines in oncology: myeloid growth factors. Version 2.2018 (2018). www.nccn.org/professionals/physician_gls/default.aspx\#myeloid_growth

60. Smith TJ, Bohlke K, Lyman GH et al. Recommendations for the use of WBC growth factors: American Society of Clinical Oncology clinical practice guideline update. J. Clin. Oncol. 33(28), 3199-3212 (2015).

61. Tsuchida S, Tsubouchi H, Kitamura A et al. Risk factors of febrile neutropenia induced by chemotherapy in lung cancer patients. Eur. Resp. J. 48, PA4842 (2016).

62. Fujiwara T, Kenmotsu H, Naito $\mathrm{T}$ et al. The incidence and risk factors of febrile neutropenia in chemotherapy-naive lung cancer patients receiving etoposide plus platinum. Cancer Chemother. Pharmacol. 79(6), 1229-1237 (2017).

63. Rapoport BL, Aapro M, Paesmans M et al. Febrile neutropenia (FN) occurrence outside of clinical trials: occurrence and predictive factors in adult patients treated with chemotherapy and an expected moderate FN risk. Rationale and design of a real-world prospective, observational, multinational study. BMC Cancer 18(1), 917 (2018).

64. Ma Q, Agiro A, Acheson AK et al. Neutropenia related hospitalization risk in lung cancer patients with chemotherapy. J. Clin. Oncol. 35(Suppl. 15), e18290 (2017).

65. Zhu Q, Hu H, Weng D-S et al. Pooled safety analyses of ALK-TKI inhibitor in ALK-positive NSCLC. BMC Cancer 17, 412 (2017).

66. Osugi J, Owada Y, Yamaura T et al. Successful management of crizotinib-induced neutropenia in a patient with anaplastic lymphoma kinase-positive non-small cell lung cancer: a case report. Case Rep. Oncol. 9(1), 51-55 (2016).

67. Blackwell K, Donskih R, Jones CM et al. A comparison of proposed biosimilar LA-EP2006 and reference pegfilgrastim for the prevention of neutropenia in patients with early-stage breast cancer receiving myelosuppressive adjuvant or neoadjuvant chemotherapy: pegfilgrastim randomized oncology (supportive care) trial to evaluate comparative treatment (PROTECT-2), a Phase III, randomized, double-blind trial. Oncologist 21(7), 789-794 (2016).

68. Maillet D, Blay JY, You B et al. The reporting of adverse events in oncology Phase III trials: a comparison of the current status versus the expectations of the EORTC members. Ann. Oncol. 27(1), 192-198 (2016).

69. Schroll JB, Penninga EI, Gøtzsche PC. Assessment of adverse events in protocols, clinical study reports, and published papers of trials of orlistat: a document analysis. PLoS Med. 13(8), e1002101 (2016).

70. Drilon A, Siena S, Ou SI et al. Safety and antitumor activity of the multitargeted pan-TRK, ROS1, and ALK inhibitor entrectinib: combined results from two Phase I trials (ALKA-372-001 and STARTRK-1). Cancer Discov. 7(4), 400-409 (2017).

71. Doebele RC, Ahn M-J, Siena S et al. Efficacy and safety of entrectinib in locally advanced or metastatic ROS1 fusion-positive non-small cell lung cancer (NSCLC). Presented at: 19th International Association for the Study of Lung Cancer World Conference on Lung Cancer. Toronto, Canada, 23-26 September 2018.

72. Roche. Roche's investigational medicine entrectinib showed a durable response of more than two years in people with a specific type of lung cancer. (2018). www.roche.com/media/releases/med-cor-2018-09-24c.htm

73. Shaw AT, Felip E, Bauer TM et al. Lorlatinib in non-small-cell lung cancer with ALK or ROS1 rearrangement: an international, multicentre, open-label, single-arm first-in-man Phase 1 trial. Lancet Oncol. 18(12), 1590-1599 (2017).

74. Source: Pfizer. EU and Japan health authorities accept regulatory submissions for review of Pfizer's third-generation ALK inhibitor lorlatinib. (2018). Press release:

https://press.pfizer.com/press-release/us-eu-and-japan-health-authorities-accept-regulatory-submissions-review-pfizers-third- 